\title{
Programmable Valve Shunts: Are They Really Better?
}

\section{Programlanabilir Şantlar Gerçekten Daha İyi midir?}

\author{
Rashim KATARIA, Vimal KUMAR, Veer Singh MEHTA
}

Paras Hospital, Department of Neurosurgery, Gurgaon, Haryana, India

Correspondence address: Rashim KATARIA / E-mail: rashim_kat@yahoo.com

\begin{abstract}
Programmable valve shunts allows selection of opening pressure of shunt valve. In the presented article, a unique complication pertaining to programmable shunts has been discussed. A 5-year-old boy who had tectal plate low grade glioma with obstructive hydrocephalus was managed with Codman programmable ventriculoperitoneal shunt. There was a spontaneous change in the opening pressure of the shunt valve leading to shunt malfunction. Routinely used household appliances produce a magnetic field strong enough to cause change in the setting of shunt valve pressure and may lead to valve malfunction. Other causes of programmable valve malfunction also discussed.
\end{abstract}

KEYWORDS: Hydrocephalus, Programmable valve shunts, Shunt malfunction, VP shunts

öz

Programlanabilir şantlar, şant kapağının açılma basıncının ayarlanabilmesine imkan verir. Sunulan makalemizde programlanabilir şantların kendine has komplikasyonları tartışılmaktadır. Tectal bölgede düşük grade gliom tanısı konulan tıkayıcı tip hidrosefali olgusunda Codman programlanabilir şantı kullanılmıştır. Şant açılış basıncında oluşan ani değişiklik sonucu şant işlev görmez hale gelmiştir. Evlerde sık kullanılan bazı araçlar şant valvinin etkilenmesine yol açabilecek kadar manyetik alan oluşturup şant işlevinin bozulmasına neden olur. Şant disfonksiyonuna yol açabilecek diğer nedenler de tartışılmıştır.

ANAHTAR SÖZCÜKLER: Hidrosefali, Programlanabilir şant, Şant bozulması, Ventriküloperitoneal şantlar

\section{MANUSCRIPT}

Background: Programmable valve shunts are considered to be better than conventional fixed pressure valve shunts as they allow the selection of he opening pressure of the valve, which reduces the complications due to over/under drainage of the cerebrospinal fluid. Spontaneous changes in the set pressure, blockage and intrinsic malfunction of the valve are some causes of concern, apart from the cost.

In the presented article, these issues have been discussed in view of literature presently available.

\section{CASE DESCRIPTION}

A boy aged 5 years presented with increased head size since birth, headache and imbalance while walking for one month. Clinical examination revealed large head circumference, truncal ataxia, impaired tandem walking, and gaze evoked nystagmus. MRI brain showed tectal plate low grade glioma with hydrocephalus. As the lesion was non-progressive and mass effect was minimal, the hydrocephalus was managed with a Codman programmable right ventriculoperitonial shunt and pressure was set at $150 \mathrm{~mm}$ of water. The patient gradually improved both clinically and radiologically before he was discharged.

He continued to improve neurologically for one and a half months, when parents noted drowsiness which gradually progressed to unconsciousness with tonic posturing over
2 days. NCCT Brain done at the local health centre showed grossly dilated ventricles. $30 \mathrm{ml} \mathrm{CSF}$ was tapped from the shunt chamber, leading to transient clinical improvement. When the patient was received at the study centre, he had a decerebrating posture with dilated fixed pupils. The peritoneal end of the shunt was exteriorized as an emergency but no CSF was seen coming out. The valve pressure was re-set at $150 \mathrm{~mm}$ of water and CSF came out in pressure, suggesting a change in pressure setting of the programmable valve. There was no history of exposure to a strong magnetic field (like MRI). NCCT head done next day showed decrease in the size of ventricles with progressive clinical improvement. He gained consciousness over the next 3 days. After thorough evaluation and history elicitation, it could only be concluded that the magnetic field produced by some house-hold electric/electronic appliance had led to a change in the pressure of shunt. Ultimately, the Codman programmable VentriculoPeritonial Shunt was replaced with a medium pressure Vygon shunt.

\section{DISCUSSION}

The Codman Programmable Valve enables surgeons to select one of 18 different pressure settings between $30 \mathrm{~mm}$ and $200 \mathrm{~mm}$ of water. The opening pressure of the valve can be changed through the use of an externally applied, graded magnetic field.

The valve works on a ball and spring that sits atop a rotating 
spiral cam with a stepper motor. When a specific magnetic field is applied to the stepper motor, the cam turns slightly and changes the tension in the spring and ball, which sets the desired opening pressure of the valve (8). This will allow the successful management of symptoms related to CSF over and/or under drainage by non-invasive change of the initial pressure setting of the valve (9) thus lowering total cost, reducing the hospital stay and increasing the quality of life (2).

The pressure setting of the shunt system can be changed by various shocks, including magnetic impulses, and the pressure level of the shunt system must therefore be constantly monitored (6). There are many sources of weak magnetic fields e.g. television, cell phones, or commercially available toy magnets that may influence a programmable valve in everyday life $(13,7,1)$. The settings of the Strata valve including the Hakim valve were affected by magnetic flux densities of 6.0, 17.5, and, $40.0 \mathrm{mT}$, respectively. Cell phones produce a magnetic flux density of 3.0 to $40.0 \mathrm{mT}$. Although cell phones could theoretically influence shunt valves, this seems unlikely because the flux density decreases with the square of the distance (7). MRI scans have also led to pressure valve changes in a significant proportion of cases but this could easily be readjusted by percutaneous manipulation $(3,12)$.

Zemack $\mathrm{G}$ et al state that more than $40 \%$ of the patients required valve pressure adjustment either one or several of times. Around two third of patients improved after pressure adjustments (14). In the presented case, it was not exactly known what had changed the pressure setting of the valve; one of a number of home appliances used commonly (as detailed) has probably led to a change in the settings of the valve.

Apart from a magnetic field, the other causes of a changing opening pressure in $2 \%$ of cases were intrinsic valve malfunction or blockage (14). One study demonstrated an intrinsic programmable valve malfunction rate is as high as $11.1 \%$ per annum, whereas there was no intrinsic valve malfunction with nonprogrammable valve systems during same period for similar causes of hydrocephalus (10). The intrinsic causes of shunt valve malfunctions are rotation of valve along its long axis, loosening of ratchet wheel, dislodgement of radiopaque marker from the baseplate and debris deposits (5). Blunt trauma also changes the opening pressure by mechanical deformation of valve ball (10).

It is mandatory that the surgeon inform the patient of the possible hazards of these programmable valve shunts. The valve selection should be adaptable to the patients' environment. To reduce the incidence of these complications, appliances with critical levels of electromagnetic flux should be replaced by ones with lower magnetic fields. The future construction of these valves should be modified in such a way that their adjustment requires a higher magnetic flux density, so that the valves become less sensitive to unwanted effects from environmental magnetic fields (11).
It is necessary that further evaluation of programmable valves should be carried out in prospective, randomized fashion to elucidate specific indications and reliability of these valve systems, as suggested by others authors in past (4).

\section{REFERENCES}

1. Anderson RC, Walker ML, Viner JM, Kestle JR: Adjustment and malfunction of a programmable valve after exposure to toy magnets. Case report. J Neurosurg 101: 222-225, 2004

2. Arnell $K$, Eriksson $E$, Olsen L: The programmable adult Codman Hakim valve is useful even in very small children with hydrocephalus. A 7-year retrospective study with special focus on cost/benefit analysis. Eur J Pediatr Surg 16: 1-7, 2006

3. Fransen P, Dooms G, Thauvoy C: Safety of the adjustable pressure ventricular valve in magnetic resonance imaging: Problems and solutions. Neuroradiology 34(6):508-509, 1992

4. Mangano FT, Menendez JA, Habrock T, Narayan P, Leonard JR, Park TS, Smyth MD: Early programmable valve malfunctions in pediatric hydrocephalus. J Neurosurg 103(6 Suppl):501-507, 2005

5. Mauer UM, Schuler J, Kunz U: The Hakim programmable valve: Reasons for reprogramming failures. J Neurosurg 107(4):788-791, 2007

6. Miwa K, Kondo H, Sakai N: Pressure changes observed in Codman-Medos programmable valves following magnetic exposure and filliping. Childs Nerv Syst 17(3):150-153, 2001

7. Nomura S, Fujisawa H, Suzuki M: Effect of cell phone magnetic fields on adjustable cerebrospinal fluid shunt valves. Surg Neurol 63(5):467-468, 2005

8. Ortler M, Kostron H, Felber S: Transcutaneous pressureadjustable valves and magnetic resonance imaging: An ex vivo examination of the Codman-Medos programmable valve and the Sophy adjustable pressure valve. Neurosurgery 40(5):1050-1057, 1997; discussion 1057-1058

9. Rohde V, Mayfrank L, Ramakers VT, Gilsbach JM: Four-year experience with the routine use of the programmable Hakim valve in the management of children with hydrocephalus. Acta Neurochir 140:1127-1134, 1998

10. Sato K, Shimizu S, Utsuki S, Suzuki S, Oka H, Fujii K: Disparity between adjusted and actual opening cerebrospinal fluid pressure in a patient with the Codman Hakim programmable valve: occult form of shunt failurem due to head banging. Case report. J Neurosurg 105(5 Suppl):425-427, 2006

11. Schneider T, Knauff U, Nitsch J, Firsching R: Electromagnetic field hazards involving adjustable shunt valves in hydrocephalus. J Neurosurg 96(2):331-334, 2002

12. Shellock FG, Wilson SF, Mauge CP: Magnetically programmable shunt valve: MRI at 3-Tesla. Magn Reson Imaging 25(7):1116-1121, 2007, Epub 2007 Jan 19

13. Utsuki S, Shimizu S, Oka H, Suzuki S, Fujii K: Alteration of the pressure setting of a Codman-Hakim programmable valve by a television. Neurol Med Chir (Tokyo) 46(8):405-407, 2006

14. Zemack G, Romner B: Seven years of clinical experience with the programmable Codman Hakim valve: A retrospective study of 583 patients. J Neurosurg 92(6):941-948, 2000 